\title{
Encounters of Indic-Abrahamic Religions with Matriliny in Premodern Southern India
}

\author{
MAHMOOD KOORIA \\ Leiden University, Netherlands; Ashoka University, India
}

\begin{abstract}
This article engages with the matrilineal communities of the Indian Ocean littoral with a focus on the southern Indian context. The matrilineal system was one of the most convenient features in the context of the Indian Ocean trade. In their transregional journeys, maritime itinerants stayed in one place for months or even a year, depending on the variations in monsoon. During this period, they married into the local communities. These marriages were enabled through the existing matrilineal practices, in which men could and should come and go while the women stayed at home and owned the property. From Southeast Asia to Southeast Africa, the matrilineal system has been prevalent in several Islamic communities, but in southern India it historically existed among Hindus and Muslims, and to some extent among Jews and Christians, too. Although the adherence to the system varied historically, we can observe certain features shared among the communities. On the basis of fragmentary but significant evidence between ca. 800 and 1800 CE among Hindu, Jain, Buddhist, Muslim, Jewish and Christian communities, I explore the nuances of conversion and incommensurability across religions. I investigate how the system benefited the oceanic mercantile culture in the region as well as the dispersal of Abrahamic religions, which are often interpreted as significant domains of patriarchy and patriliny.
\end{abstract}

KEYWORDS matriliny, Abrahamic religions, Indic religions, Indian Ocean, South India

\section{Introduction}

The origin of the matrilineal system has been a matter of long debate in academia, with an early generation of social anthropologists, philosophers, archaeologists, feminists and linguists arguing for its prevalence since the prehistoric period (for a survey and critique, see Eller 2011). Going beyond a search for origins, historians have rarely studied the premodern histories of the existing matrilineal communities. In this article, I engage with some of these groups in the Indian Ocean littoral with a focus on southwestern India. I argue that the 
maritime culture and diverse religious traditions contributed to and benefited from the matrilineal systems in the region, and that a close observation of both matrilineal and maritime histories over the longue durée demonstrate that the social structure in the oceanic littoral was shaped by their mutual entanglement.

The matrilineal system was one of the most convenient ways for facilitating Indian Ocean trade, and many matrilineal communities were dependant on oceanic trade through a giveand-take relationship. In their transregional journeys, maritime itinerants stayed in one place for months or even a year, depending on the variations in monsoon seasons. During this period they could and did marry local people thanks to existing matrilineal practices, according to which men could come and go while women mostly stayed at home and managed the property. This social stability provided women the upper hand in economic, socio-cultural and personal choices. From Southeast Asia to Southeast Africa, the matrilineal praxis has been prevalent in several maritime communities in Mozambique, Comoros, Kenya, Somalia, Indonesia, Malaysia, Sri Lanka and India. Although the degrees of women's centrality in the system varied historically from community to community and from place to place, this social system couched two major types across regions: matriliny and matrilocality. The lineage and inheritance through the mother's line constituted central elements of the former, while residential patterns of men at their wives'/mothers' places determined the latter. Relatedly, some scholars have observed the existence of a third type, matriarchy, in some of these communities as they emphasize the power women enjoyed in public, private, political, social and economic spheres.

In the Indian subcontinent, the system has historically existed in southwestern, southeastern and northeastern coasts and hinterlands. The prevalent historiographical understanding has been that Abrahamic communities such as Muslims received the system from local Hindus. For example, Romila Thapar, a leading Indian historian of the ancient period, wrote at the turn of this century: "Matriliny and matrilocality, for example, were characteristic of the Mappilas but not of the other [Muslim]s. These customs appear to have been borrowed from the local Nair practice, since they would otherwise seem unacceptable to conservative Islam" (Thapar 2003, 332). Similarly in the early twentieth century, a prominent historian of Kerala, K.P. Padmanabha Menon (1924, 562), who was an expert on the matrilineal system and a member of the Marumakkattayam Committees of Travancore and Cochin, ${ }^{1}$ wrote about the law of inheritance among Kerala Muslims: "As regards their law of inheritance and testamentary powers, they follow the precepts of the Koran [sic], though there are Mahomedan Mappilas in North Malabar and in Travancore who have retained the Nayar system of succession by nephews" (Menon 1924, 562). Going back even further, in the sixteenth century another historian from the region identified the system as a Hindu custom influencing Muslim life: "This tradition [among the Nayars] of denying inheritance to one's own children has crept into the majority of Muslims in Kannur and the neighbouring areas, following them [the Nayars], despite the fact that they read the Quran, memorize and recite it beautifully, study religious knowledge, and occupy themselves with prayers" (British Library IOR, MS. Islamic 2807e: $125 r$ ).

I challenge this conventional wisdom that Muslims (and others) adopted the system from the Hindu community. Matrilineal praxis was a wider social phenomenon in the Indian sub-

1 The committee was founded to recommend necessary changes in the matrilineal system among the Nayars (also commonly written as Nairs), one of the most prominent matrilineal groups in Kerala at the time. The marumakkattāyam is a widely used Malayalam word for matrilineal system. 
continent, and it existed independently of religious affiliation, as we can see it among both the established Abrahamic-Indic religious communities as well as indigenous tribal communities. Being attentive to this diversity of the system and its probable presence in prehistoric and early historic communities, I argue that the religions (especially the Abrahamic religions) have contributed to its sustenance in the region across centuries. In the process of sustaining the foundational systems of lineage and residential pattern, these religions reformulated the system to befit their own worldviews.

On the basis of fragmentary but significant evidence from 800 to $1800 \mathrm{CE}$, this article explores the nuances of conversion and incommensurability across religions in the southern parts of the subcontinent. I investigate how the system benefited from the dispersal of Indic (Hindu, Jain and Buddhist) and Abrahamic (Jewish, Christian and Islamic) religions, which were often interpreted as significant domains of patriarchy and patriliny. I argue that the system existed in the region when most of these religions appeared in the scenario, including Hinduism, and therefore it is not wise to say that one religion exported the praxis to other communities. In what follows, I start with a brief overview of the historiographical debates on prehistoric and early historic evidence of the system in South Asia. I then describe and analyse some major matrilineal communities of southwest Indian coasts and islands with potential comparisons and connections, and focus on the Abrahamic religious communities and their engagement with matriliny before zooming in on the question of religious conversion. The approach is primarily historical as it examines epigraphic, textual and material sources.

\section{The Prehistoric and Early Historic Questions}

Until the late twentieth century, many historians and archaeologists argued that matrilineal and matriarchal systems existed across South Asia in prehistoric and early historic periods. The argument went like this: the indigenous non-Aryan communities were matrilineal, and the patriarchal Aryans dominated and changed the system while pushing the matrilineal groups to the margins. In a pre-class society, the tribes organized their social and familial systems through the prisms of matriarchy. A tribe was divided into exogamous units, the clans, which were divided further into groups of five or six households. Primitive marriages took place between the members of the tribe (endogamy) but outside the clan (exogamy), and this helped crystallize the clan units. "The first marriages were between groups, the first clans matriarchal, descent and inheritance were in the mother's line, the father being of no importance, often not even recognized as having any pro-creative function" (Kosambi 1975, 22). Through this matriarchal lens, scholars interpreted the vedas and epics with such arguments as some characters being symbols of matriarchal cults dying under the patriarchy of the Aryans or through intermarriages between the Aryan men and non-Aryan women (Thapar 2013, 134; Kosambi 1962, 42-81; Gaur 1974). The excess of female figurines or goddesses in the prehistoric Harappan Civilisation is also understood as an exemplification of the matriarchal system (Kosambi 1975; Thapar 2003). ${ }^{2}$ Kosambi worked with the older Marx-Engelsian argument that society normally developed from matriarchy to patriarchy, and argued that this

$2 \quad$ On the remarkable presence of female figurines and their potential worship in the Harappan as well as later cultures, Thapar $(2003,94)$ writes that "this need not point to the prevalence of a matriarchal system. Matriarchies would have been unlikely to approve of headless female figures, even as objects of worship. But it does point to a greater social presence of the female than in later times, which may also have been a generally more assertive presence." 
"normal sequence of development" was disturbed by the assimilation of "non-Aryan Indians to the Aryan way of life and of speech" $(1975,86)$.

As Friedrich Engels and those who followed him have argued for the existence of such systems in the prehistorical world, his thesis found roots among scholars of India well up to the late twentieth century. Not only regarding the presence of matriarchal institutions in prehistory did historians of the Indian subcontinent go one step further by attributing many characteristics to the living "matriarchal institutions". Arguments on the absence of private property in some of these communities was a telling instance for them, as Kosambi writes on "Travancore-Cochin and among some tribesmen," among whom "originally, there existed no concept of property except for the few tools prepared by the individual, which supposedly contained some extension of his personality (mana)" (Kosambi 1975, 22). He says that land was territory, not property, and all the gathered food was shared out to all, and "male dominance came only when the special property of men developed" through cattle herded first for meat, then for milk products and skins, and finally as a source of power in agriculture and transport. In the process, "man first produced a greater surplus by his labour than was necessary to support the individual producer himself. Thus patriarchy, individual property, class division became possible, though not always inevitable."

Cynthia Eller has rejected such arguments that emerged from the late nineteenth century onward among such early social anthropologists as Lewis Morgan, John McLennan, Henry Spencer and John Lubbock and taken up by socialist ideologues like Karl Marx and Engels. Taking a different stand, some anthropologists of the Indian subcontinent argued that the matrilineal and matriarchal institutions in the region should be understood separately. Umar Rolf Ehrenfels, an Austrian anthropologist of Indian matrilineal institutions, remarked in the mid-twentieth century that the common assumption of matriliny preceding patriliny had no relevance in the subcontinent, especially as the underlying argument is, "all human societies must at one time have passed through a primitive, evolutionary 'stage' of matriarchy" (1953, 357). The latest ethnographical research of his time had shown that the primitive food gatherers were neither matrilineal nor patrilineal, but generally followed the bilateral type of social organization. His argument in support of the matrilineal system in the region thus emerged from his awareness of the longer socio-cultural processes that these communities came through, and the system seemingly "developed as a product of a higher, plant-cultivating village civilization."

While the arguments on the prehistoric communities are hard to substantiate on the basis of convincing evidence, scholars also have put forward similar arguments for the historic period. Accordingly, the Satavahanas of the Deccan region in the first millennium of the Common Era are said to provide evidence of matrilineal system. Various textual and epigraphic sources from the last centuries BCE and early centuries CE demonstrate that the rulers and others identified themselves as children of their mothers rather than their fathers and that they preferred maternal relatives over paternal ones. Some inscriptions show that the inheritance was to be transferred through the female line. Kosambi $(1975,246)$ says that the Satavahana custom of reporting the mother's gōtra name "may, but need not, indicate some remnant or original mother-right; for it can be explained as due to polygamy. The mother's gentile name served to distinguish the son from his stepbrothers, while showing respectable birth on both sides." ${ }^{3}$ Thapar $(2003,228)$ makes a neutral statement that the Satavahana use of

$3 \quad$ Echoing Kosambi, Olivelle (2013: 488) writes on this: "One can understand this in light of the fact that Indian kings had multiple wives, whose sons often vied with each other for the right of succession. [....] A 
matronymics "has led to the controversy as to whether this was a method of identifying the ruler more precisely or the influence of a local matrilineal custom."

The existence of such diverse customs as dowry (strìdhana) and marrying maternal uncle's daughters among several Indian communities also has been interpreted as remnants of a matrilineal underlayer in the subcontinent's past (Thapar 2013, 191, 332-33, 396, 2003, 304; Kosambi 1975, 86). In the context of such systems of cross-cousin marriages, Thapar (2003, 466) writes that "the inheritance of the daughter had to be mentioned, as was sometimes done in inscriptions. In some areas, the wealth given and gifted specifically to a woman, her strìdhana, could now include immovable property", and cross-cousin marriages ceased in elite circles of northern India because "the normative texts supported patriarchy" and those wanted upward social mobility needed to adopt the same pattern (Thapar 2003, 304).

In southern India, the system seemingly existed when the region moved from prehistory into the light of history at the turn of the last century BCE. The Greek author-cum-diplomat Megasthenes mentions in the third century BCE that one of the prominent southern kingdoms, that of the Pandyas, was established by the daughter of Herakles, and the Pandyan queen had an army of 500 elephants, 4,000 cavalries, and 13,000 infantries. "Perhaps this reflects the matrilineal society of early south India, which survived on the west coast in Kerala until half a century ago" (Thapar 1966, 2:103). Historians take contrasting standpoints on the question of whether the Chera dynasty followed matriliny in the succession to the throne: some argue that they were indeed matrilineal, while others reject this thesis (Dikshitar [1933-1934] 1966, 255-67, 1939, 12-13; Kunjan Pillai 1970; Narayanan 2013, 292-93).

The currency of the system in the prehistoric communities is yet to be explained convincingly, and it is difficult to prove its origins and evolution on the basis of solid evidence, for archaeological and anthropological studies become more interpretative and imaginative than the evidence self-substantiate. Nevertheless, I strongly believe that the historical (in contrast to prehistoric) communities can provide substantial insights into the practice in the premodern period and the extent of its influence on southern Indian societies. Such an investigation into the origins of the system and its early adherence by a specific community is however beyond the scope of this essay. For now, we only need to keep in mind that many matrilineal communities have historically depended on trade, and diverse commercial activities benefited from and contributed to matrilineal institutions, such as marriage with foreign traders or other outsiders and inheritance of surplus through the female line. Overseas and overland trade, trading communities and mercantile surplus enabled the survival of the system. Among many other issues, this dimension specifically calls into question Kosambi's arguments on cattle herding providing men surplus and thus leading to patriarchy.

\section{Matrilineal Coasts and Highlands}

There are many living communities in the Indian subcontinent with matrilineal systems or its visible traces. Most of these are in southern India, but also in northeastern India. In the southwestern region, Kerala is the most prominent and well-known matrilineal realm, thanks to the well-studied group of the Nayars (Arunima 2003; Gough 1954; Kodoth 2002, 2004). However, the Nayars were not the only matrilineal group in the region and Kerala was not the only place with matriliny in southern India. In varying levels, the system has historically

king's paternal relatives are also related to his brothers, whereas his maternal relatives are connected only to him." 
existed among many other groups in Kerala as well as in Karnataka, Tamil Nadu, Goa, and the Lakshadweep Islands.

In the case of the most known realm of Kerala, the system gained enormous attention in the political, juridical, social and religious spheres since the nineteenth century with discourses centred on the Nayar community, but from early on scholars such as Padmanabha Menon (1924, 30) and Hermann Gundert $(1872,793)$ have noted that the system prevailed among other communities too. Gundert enumerated about twenty such groups, including Brahmans in Payyanur, Ksatriyas, Pisharadis, Variyans, Nambis, Teyambadis, Nedungadis, Vallodis and Tiyans. The matrilineal practices thus crossed not only religious boundaries, but also caste boundaries, regardless of upper and lower caste hierarchies.

Beyond Kerala, the Tuluva subgroups in Karnataka, such as Bunts (including the Jain Bunts), Billavas, Kulalas, Devadigas and Mogaveeras, followed the system known variously as aliya santāna kattụ, aliyakațu (law of children of the brother-in-law) or mūliya paddhati (original custom) vis-à-vis the patrilineal system called makkala santāna kațtu. They transferred property through the mother's line and the lineage identity through mother's tribe or ancestral house. The bali or bari (equivalent to gōtra) was important in the marriage. Members of the same bali did not intermarry in some groups, as children belonged to their mother's bali and therefore a boy and a girl from the same bali were considered siblings, whereas some groups preferred cross-cousin marriages. Unlike the Brahmanical textual proscriptions, remarriage of widowers or divorcees was common, and divorce was permitted with social sanction.

The Nayars and Bunts had several similar social and economic features along with the obvious social structure of matriliny. Both groups owned lands and worked in the military and as intermediaries in both politics and trade. In essentially agricultural regions, they were the main land-owning classes but they also engaged prominently in martial and mercantile occupations. The term nāyar connoted military leadership, while bunt meant a strong person and soldier. For a long time, historians associated the origin of matriliny with the military occupation of premodern Nayars, who went to battle constantly and were unsure of their return. This constant absence of men arguably motivated women to take over the property rights and pass them over through the female line alone. This claim has been questioned in the last two decades by scholars such as G. Arunima (2003), who argued that the Nayars were also an agrarian society and the military occupation was only marginal. Gamliel (2018) shows that they were also mercantile intermediaries. Harald Tambs-Lyche $(2018,216)$ writes that the ancestors of the Bunt chiefs "must have been 'tribals' in the interstices between the trade routes controlled by the Jain kingdoms," and when the river valleys of the intermediate zones "were drained and prepared for rice cultivation" in the fifteenth and sixteenth centuries and led to the establishment of a new village structure, the Bunts became chiefs while the tenants and labourers were Billavas. Before and after this transition, the "Bunt chiefs were heads of matrilineal lineages and thus retained what Stein calls a 'tribal' base" (Tambs-Lyche 2018, 216). K.V. Ramesh, a stalwart of the region's premodern history, says that the Jain rulers who generally followed the matrilineal system contributed to its expansion across their dominions and adjacent places (1970, 279-81). In the new village structure of the early modern period, the Bunt chiefdoms prospered as the ruling dynasty of Ikkeri Nayakas extended their authority to south Kanara in the seventeenth century while the power of the Jains declined (Tambs-Lyche 2018, 216). Similar to the Nayar-Bunt comparison, the Billavas of Karnataka are compared to Ilavas and Tiyyas of Malabar, who all worked in toddy-tapping and coconut 
planting, and their kinship terms were similar and they practiced matriliny (Karve [1953] 1965, 271).

An early connected statement on the matrilineal systems of both Karnataka and Kerala comes from the fourteenth-century Roman Catholic missionary Friar Jordanus, who came to Quilon in 1324 to convert the Nestorians to the Roman tradition. Pope John XXII appointed him subsequently as Bishop of Quilon or Columbum, the first Catholic See in India (Menon 1924, 281-2). In his Mirabilia Descripta, he says that "the king of Columbum is called Lingua but his kingdom Mohebar." The translator Henry Yule notes that this king Lingua is probably connected to the sect of the Lingayets in Karnataka, although he misidentifies the ruler as a Nair on the basis of Jordanus' description on the law of succession (Jordanus 1863, 39-41). He makes similar remarks on the rulers of Coorg "who were both Nairs and Lingayets." On the system of descent and inheritance in the female line, Jordanus wrote: "In this India never do [even] the legitimate sons of great kings, or princes, or barons, inherit the goods of their parents, but only the sons of their sisters" $(1863,32)$.

On the prominence of matrilineal system in Karnataka, the best sources are the folksongs called päddanas. They are repositories of Tuluva culture and they expound on the instincts of Tuluva mother, the predominant figure in a matrilineal society. They shed light on the system, including women's social and economic status, rights and duties in society, inheritance issues, conflicts with patrilineal neighbours, resolutions through the court of justice (patteri kuta), the heroine's enforcement for divorce and her defiant and mimic gestures against the stigma of a divorcee or widow (Honko 1998; Burnell 1894). The best example is the epic on the heroin Siri, an ancestress of the Tuluvas and venerated as such both in the northern and southern Tulunadu.

In Tamil Nadu, the matrilineal subcastes of Nangudi Vellalars or Cevalai Pillaimars and Kottai Pillaimars shared many features, such as residence patterns, inheritance and many similar oral traditions (Bharathi 2004), while other castes and subcastes, such as Kondaiyamkottai Maravars, maintained matriliny through several social and familial traditions, such as bride price and marriage with close kin or more specifically from matrilateral kin through crosscousin marriages (Fawcett 1903; Kapadia 1994). Many more non-Brahman Tamil groups put greater emphasis on matrilineal and matrilateral kinship, such as the "untouchable" Pallars and Roman Catholic Paraiyars (Christian Paraiyars), the agriculturalist Muthurajahs and the wealthy Vellan Chettiars. Accordingly, the system prevailed in several parts of Tamil Nadu, such as Tiruchi and Tirunelveli, up until the mid-twentieth century. In southern parts of Tamil Nadu, some communities were both matrilineal and patrilineal. One example is Kallars of Tanjore and Madura districts, studied by Louis Dumont in the mid-twentieth century. Their practices have motivated scholars to assume a wider existence of matrilineal institutions in the Dravidian South as much as their cultural exchanges with the communities in Kerala (Karve [1953] 1965, 308). ${ }^{4}$

The matrilineal practice among Tamils in Sri Lanka is well studied (McGilvray 2008; Goody and Tambiah 1973; Tambiah 1954), and scholars have analysed common elements between Marumakkattāyam of Malabar and Tesavalamai (traditional laws of Tamils) of Jaffna (Raghavan 1971; Ehrenfels 1941, 1953). Similarly, people in the Lakshadweep Islands have long maintained the matrilineal tradition. Several anthropologists and legal scholars have analysed its continuities and ruptures in the nineteenth and twentieth centuries (Dube 1969; Kutty 1972; Forbes 1978; Abraham 2017). Although marginal yet important traces of similar prac- 
tices existed in Bardez in Goa, where women hoed their small plots and men were required to go abroad to earn money (Kosambi 1975, 52, n. 11).

The matrilineal system among all these communities was not fossilized or undifferentiated, but there were diverse dissimilarities, as Iravati Karve ([1953] 1965, 292) has noted just on the case of Kerala: "The small area where Malayalam is spoken contains almost all forms of family-organization found elsewhere in India." This comment is particularly important as it comes out of her extensive study on family and kinship organisations across India. Earlier scholars have categorised four major matrilineal systems in south India, in addition to a fifth one from northeast India (Ehrenfels 1941). To illustrate the differences broadly, some communities adhere to a women-dominated system with much political and religious power in the hands of the clan matriarch or head, while several others follow matrilineal or matrilocal customs in a patriarchal setting where women do not have much control over the everyday working of the family and society at large. Such drastic differences between these communities might have evolved over time, and they define the nuances of the matrilineal system in the respective communities. The system became a matter of long jurisprudential and political debates since the late nineteenth century, when lucid codifications of the related customs as Marumakkattāyam or Aliyasantāna niyama were initiated by the colonial administrators and community members in order to control the socio-economic and cultural dynamics of the communities. In the legislative assemblies of the colonial Madras Province, representatives from Karnataka and Tamil Nadu engaged in heated deliberations in the early twentieth century, while the debates continued in Kerala and Lakshadweep up until the late twentieth century on the division of matrilineal household properties and the managerial roles of the senior-most male members (Arunima 2003; Kumar 2006; Shukkur 2007).

\section{Indic Religions}

The matrilineal system was much persuasive, from the southwest to the southeast of India, but did Indic religions play any exclusive role in the related institutions? Was matriliny a Hindu social system, as many scholars cited above have claimed?

To address the latter question first, the direct answer is negative. The tradition was not a Hindu social system, primarily because almost all of the doctrinal, jurisprudential and legal texts of Hinduism conceived and propagated an inheritance and lineage system that was patrilineal and patriarchal. This worldview is universal across enormous amounts of texts produced in the subcontinent that defines the Hindu tradition, and it is only much later (possibly in the sixteenth or seventeenth century) and from southwestern India alone that there is some juridical substantiation for the matrilineal system in the Dharmaśāstra texts (Davis Jr. 2013). Way before the system was taken into consideration by such Brahmanical texts, the system had existed in the region across religious borders. Furthermore, in the everyday life, many people (including Brahmans and Ksatriyas) and texts (including the vedas and epics) observed the system in varying degrees. This was not because the system was reconciled with Brahmanical ideologies, but because the system suited the priorities and meaning-making process of the individual groups.

The latter point is important as it resonates across the borders of Indic religious communities. The system existed independently of religions, yet these provided useful interpretative and analytical frameworks for followers to justify the praxis. In doing so, Indic religions contributed to its sustenance. In southern India, this becomes rather evident once we trace the 
early histories of matriliny with regard to religions. Historians agree that it was in the seventh and eighth centuries that Brahmanism made its vital presence in southern India, even though its earlier forms existed much earlier (Nilakanta Sastri [1935] 1955, 635-42) (Nilakanta Sastri [1955] 1958, 411-25; Minakshi 1938, 175-85; Zvelebil 1973, 192-97). Until then, Jainism and Buddhism had an extensive followership in the region, and these "heterodox religions" reached their golden periods in the fifth and sixth centuries, pushing the earlier Brahmanism to the margins. Against this, Brahmanism was revived through the Bhakti movement under the Śaivism (and to some extent Vaiṣnavism too) in the seventh and eighth centuries, marking its prominence in the region ever since. Southwest regions such as Kerala witnessed the arrival of large numbers of Brahmans in this period (Narayanan 2013; Veluthat 1978). Even so, Brahmanism did not manage to wipe out the Buddhist and Jain influence in the region, and both religions continued to maintain a steady adherence for some centuries more. Jainism had a vital influence at least until the thirteenth century, while Buddhism maintained its followership until the sixteenth century (Monius 2001; Orr 2000; Ayyangar 1922). In Karnataka, south Kanara became "a last refuge of Jainism" in southern India and epigraphic and textual evidence attests the advancements of the religion since the twelfth century (Honko 1998, xxiv).

The second half of the first millennium CE is thus crucial in the flourishing of the three religions in the region. While the fifth and sixth centuries were important for Jainism and Buddhism, the seventh and eighth centuries were important for Brahmanism. By the time the latter rose into prominence, matriliny had already gained or sustained a solid foot in the region, as we see in the case of Buddhists, Jains, etc. Even so, Brahmanism did not alter the system altogether, rather it carved out a niche for its own in the system through conjugal alliances (sambandham), specific inheritance regimes (mātrpāramparya), etc. Eventually, the incorporation of the system into the rigid caste hierarchy and Brahmanical ideologies (if not to the didactic and prescriptive texts as such) contributed to the very survival of matriliny across generations as much as to the patriarchal skeletons of Brahmanism.

Brahmans are said to have introduced the patriarchal system to the matriarchal and matrilineal societies. After their relatively late arrival on the southwestern coasts, their patriarchal clans remained intact in their settlements in agriculturally rich areas while benefiting from the matrilineal customs. The Brahman immigrants had very few women among them, like most immigrants elsewhere, and they had to work with customs and cultures they were not very familiar with. The intermarriage with local communities helped them overcome such hurdles, and local recruitment into Brahmanical folds was supported through prescriptions in the smritis, which advocated that seven generations of intermarriages would make a Sudra into a Brahman (Kosambi 1975, 319). The Nayars in Kerala invested in such regular intercourses, as did many more communities across the subcontinent from Nepal and Bengal to southern India. Even the ancient kingdom of Champa in present-day Cambodia is said to have been founded through similar intercourse. ${ }^{5}$ Yet, the Brahmanical adjustment to matrilineal societies of southwestern India, as evident in the relationship between Nambudri Brahmans and Nayars, "took a different form from those recognizable in other parts of the subcontinent" (Thapar 2003, 332). That is how the Nayars were well placed in the caste hierarchy of the Brahmanical fold while maintaining their matrilineal traditions.

5

Kosambi $(1975,319)$ notes that an Indian high-caste adventurer, Kaundinya, in the Champa region, "cowed the local aborigines by superior prowess in archery and married their 'Naga' chieftainess Soma to found a prosperous dynasty." 
Early evidence on the matrilineal system among the Nayars comes from the time of the Cheraman Perumals of Mahodayapuram (ca. 800s-1100s). The Tiruvalla copperplate inscription, published in the Travancore Archaeological Series (vol. 2, part 3, plate 38, line no. 544, p. 203), refers to marumakkal, indicating succession rights through matrilineage. ${ }^{6}$ MGS Narayanan says that the Nayar community did not have a historical presence in Kerala before the ninth century, when we have the earliest reference to the title Nayaka in an inscription (Narayanan 2013, 274). He argues that the term and its variant Nayan referred to their occupation as military-political positions, and they were born out of the conjugal relationships of Brahmans with the local Dravidian elites. Bhargava Brahmans likely recruited and trained indigenous tribes for military service and introduced the title Nayaka for them (similar to its variants such as Nayak, Nayadu, Naidu, Nayga and Nayar across many neighbouring regions) (Narayanan 2013, 290-91). In the Tiruvalla copperplates, the very name Nayar appears as a title as well as a reference that the Nayars "were following the matrilineal system of inheritance" in this period (Narayanan 2013), 274]. Questioning earlier arguments that matriliny originated following the prolonged Cola wars in the tenth and eleventh centuries (Kunjan Pillai 1970: 134-210), Narayanan thus suggests that "elements of tribal matriarchy survived in Kerala" and the newly settled Brahmans gave a new life to the institution. He assumes that a new class of people born to Aryan Brahman fathers and Dravidian mothers emerged in the post-Sangam period and this class, favoured by the Brahman oligarchy in the army and administration, might have formed the nucleus of the Nayar subcaste (Narayanan 2013, 29293). While they were seldom mentioned in the Tamil Sangam literature, now they recur in the inscriptions along with references to matrilineal forms of kinship relations and inheritance patterns, such as marumakkal and their entitlements to properties. All these indicate that the Nayars emerged as a new hybrid class/caste out of the conjugal relationships the patrilineal Brahmans maintained with the matrilineal Dravidians in the ninth and tenth centuries. Even so, we should be cautious about sweeping generalizations on the lineage patterns among Dravidians vis-à-vis Aryans as a monolithic group with only one form of succession and kinship relations.

As Jainism was prominent in the region before the dominance of Brahmanism, it is worthwhile looking at the traces of the system in its historical existence. Now the system is known mainly among the Jain Bunts of the Konkan coast. Their matrilineal specificities await an indepth historical study, but at the moment we can get some glimpses of matrilineal customs as evident in the Jain epic Cilappatikāram, composed by Ilanikō Ațikal in the fifth or sixth century, such as its references to the high bride-prices (pariyam) offered by several Cettiyar merchants to the heroine Kannaki, and to the prominence of maternal relatives in critical moments. It is quite possible that the matrilineal system in the community predates the aforesaid inscription of the Tiruvalla copperplates. Even after Brahmanism became prominent, the Jains continued to influence certain portions of southwestern India, as we saw above on the collaboration between the Bunts and Jains when the Jain kingdoms controlled the trade routes in the river valleys of the intermediate zones. The Bunt chiefdoms prospered while the power of the Jains declined in the seventeenth century (Tambs-Lyche 2018, 216). The matrilineal system sustained among several Jain communities is comparable to the growth of the Navayat Muslims

6 MGS Narayanan refers to this inscription in a documentary film Marumakkattayam, dir: P.T. Kunjimuhammad https://www.youtube.com/watch? $\mathrm{v}=9 \mathrm{VnfAwJWa0Q} \& \mathrm{t}=507 \mathrm{~s}$ (last accessed 31 August 2021), starting from 7:10; also see Narayanan (2013, 274, 293). I am thankful to Lekshmi Chandran for guiding me to the original inscription published in "The Huzur Office Plates of Tiruvalla" (TAS, vol. 2, part 3, plate 38 , line no. 544, p. 203). 
on the Konkan coast (Thapar 2003, 332). On the Coromandel Coast and in northern parts of Tamilakam, the practice found roots among certain Jains and Hindus as inscriptions and textual sources from the twelfth and thirteenth centuries demonstrate that the women of palaces and temples in Kanchipuram, for example, were involved in mothers' family networks, and their children (whether they were princes, priests, nobles or servants) were identified with reference to their mothers rather than fathers (Orr 2015, 305-6). The sons and daughters in the palaces and temples would become "vectors of maternity" as they "might inherit their mother's clan or dynastic affiliations, or adopt and extend the donative patterns established by their mothers" (Orr 2015, 311). This practice of adherence to a mother's name resonates what Kosambi (1975, 244-46) had mentioned about the Satavahana dynasty, and it is worth noting that some of its prominent kings were adherents of Jainism. Relatedly, the longue durée of matrilineal practices should also be emphasized, because the evidence for such foundational lineage practices seems to be consistent for over a millennium, despite the movements of people and the rise and fall of kingdoms and dynasties. This of course does not mean that the system itself did not undergo any changes over time; on the contrary, it became more complicated and advanced with increasing evidence on its various forms and contents.

Followers of the other important religion in this context, Buddhism, are also said to have contributed to the making of matrilineal cultures in southwest India, according to one of the first studies on the topic (Ehrenfels 1941). The Tamil Buddhist epic Manimekalai, written by Maturai Kūlavāṇikkan Cāttañār in the sixth century CE, tells the story of a heroine who renounces her matrilineal family tradition of courtesanship in favour of itinerant asceticism. Powerful and influential women appear throughout the story, especially as the heroine's maternal relatives, who persuade her on different occasions. On the potential matrilineal tradition of the Cheras, William Logan ([1887] 2010, 221-2) describes various local mythical narratives in which the ruler Sana Perumal is identified as a convert to Buddhism and Cheraman Perumal as a convert to Islam. Although marginal and outside the subcontinent, the Buddhist-matrilineal nexus is also a living tradition among the Mosuos in Yunnan in southwest China and the Karens in western Thailand (Waihong 2017; Sirisai, Chotiboriboon, and Sapsuwan 2017).

Taken together, Hindu, Jain and Buddhist communities do provide evidence of their shared entanglements with matriliny. At large, female followers of these religions in southern India enjoyed considerable freedom compared to their counterparts elsewhere in the subcontinent, and they could and did act as autonomous agents and acquired, possessed and alienated property "without permission or interference from others", as Lesli Orr $(2000,130)$ has argued in the context of donations from Hindu, Buddhist and Jain women to religious institutions like temples and shrines, rituals, gods (such as Tirthankaras and Buddhas) and monks in medieval Tamilakam. Orr argues that women's behaviour and public life in the region were not constrained by the norms enshrined in such religious scriptures as Dharmaśāstras. Therefore, it is no wonder that such a social system as matrilineal praxis did not find its way into the normative texts until much later. At large, all this evidence demonstrates that matriliny is not an exclusively Hindu custom. Rather, Brahmanical institutions and communities benefited from the system as much as they contributed to its survival in the region, the same way that Buddhist and Jain institutions and individuals did. 


\section{Abrahamic Experiences}

The discussion above was mainly about Indic religious communities. What about Abrahamic religious groups such as Jews, Christians and Muslims who frequented the port towns of the subcontinent and established their own communities? Regardless of religious differences, the long wait for favourable travel weather and infrastructures in light of monsoon seasons motivated many of them to marry local women and establish a temporary or permanent home. Historical records demonstrate the practices of polygyny and marriages of such itinerant men with local women. ${ }^{7}$

Across the Indian Ocean at large and specifically in the southern Indian littoral, such marriages between itinerants and locals often happened in the intermediary groups who worked as agents for foreigners. The Bunts and Nayars became significant in this regard as they were key middlemen in the pepper trade (Kieniewicz 1986), and marriages or cohabitation with the women of their matrilineal households resulted in peculiar inter-caste, inter-religious, hybrid social phenomena. Women brought with them the local social, familial, cultural, economic and political networks in service of the new entrant to the family, the putiyappila, in addition to a home and licit sexual relation. ${ }^{8}$

Similar to the Indic religious communities in the region, the second half of the first millennium was crucial for the Abrahamic communities, too. It was in the eighth and ninth centuries that the presence of these religions began to be prominent in the historical records, even though they must have arrived in the region earlier. In the ninth century, we have instances in which all the three communities come together on a land grant in Kollam, and we have other individual records on their presence in the region ever since.

Muslims were the most dominant mercantile group in the Indian Ocean until the sixteenth century. Accordingly, the tenth-century Arab geographer and traveller Abū al-Hasan 'Alì alMas' $\bar{u} d \bar{i}$ (c. 896-956) talks about a new generation of Muslims, at Indian ports such as Saymur (Chaul), who were fathered by Arab merchants to local women (al-Mas' ${ }^{\mathrm{u}} \mathrm{d} \overline{\mathrm{i}}$, vol. 1: 187 as cited by Lambourn 2018, 62). The bayāsira, as they were called, numbered up to ten thousand, a number symbolic of their significant presence in the region. Jews and Christians from the Middle East were also influential in the Indian Ocean trade. The Geniza records shed light on the Jewish side (Ghosh 1992; Goitein and Friedman 2008, 69-73), with intermittent references to marital issues, conversions and cohabitation with non-Jewish women and abandoned wives (Perry 2014, 156, 176, passim; Gamliel 2018, 63). For the Christian side, we have references to their marital relationship with the southern Indian communities from the ninth century onward, if not earlier (Gamliel, Forthcoming). Such relationships became more frequent in the sixteenth century when Europeans arrived on the Indian coasts in large numbers. A telling example is a census of Christians at the fort of Cochin conducted in 1514. It records that the fort was home to "fifty-eight households in which Portuguese men had taken wives from across the Indian Ocean region-from Socotra to Java, via Gujarat, Kanara and Malabar, and including also women described as Nairs and Brahmins" (Lambourn 2018, 62). These cou-

$7 \quad$ For a comparative discussion on this, see Lambourn (2018, 62-63). In a footnote (no. 106), she mentions that latest research in human genetics substantiate how quickly male sojourners, of any faith, lead to fathering a new community.

8 Lambourn (2018, 61-62) adds another dimension to this historical process, as she says that many Indian maidservants were sold to the Middle East on a regular basis, "including to Jewish families," and it also proves "the existence of such a trade even if southern Indian sources are quiet on the subject". Perry (2014, $170-72,175,191$ ) provides details of some exact purchases of Indian slave-women and slave-girls by the Jewish merchants for their associates and relatives in the Middle East in the twelfth century. 
ples had produced forty-two children while forty-five children were born out of wedlock to other non-European women. This data shows the commonality of such an intermarital system across the oceanic littoral in which recent entrants, such as the Portuguese, could marry and establish families within two decades of their initial presence in the Indian Ocean.

Socio-linguistically, the usage of the term mäppila in Kerala is most indicative of this relationality. Although it now refers mainly to Muslims, the term was historically used for all three Abrahamic communities in the region. Scholars differ on what it precisely meant, but it interrelates the marital and maritime connotations (such as mā falläh, not farmer, thus trader; mahāpillla, or great son, thus son-in-law; husband; muwallad or creole; māman pilla, or uncle's son). The latter meaning in particular is suggestive of matrilineal associations in which crosscousin marriages were common in a systematised normative order in which the potential cousin partners are identified as muraccerukkan or murappeṇu and marumakan or marumakal (for both children-in-law and uncle's children).

Matrilineal Muslims were not counted in the early lists of matrilineal communities in Kerala (for example, Gundert 1872, 793), but they were recognised as such by the end of the nineteenth century, thanks to increasing legal battles initiated by the Muslims of Thalassery and Kannur for and against the delineation of matrilineal household (taravātu) properties. The praxis is very clear among Muslims as it continues to be a strong form of family system in northern Malabar, but it is not limited to there: Muslims in port-towns such as Quilandy, Calicut, Parappanangadi, Tanur, Ponnani, Kodungallur and all the way south to Edava practiced or continue to practice matrilineal, matrilocal systems. Beyond Kerala, the Navayats in Karnataka, Marakkayars in Tamil Nadu and Lakshadweep Islanders are the other noticeable matrilineal Muslims. Arab-Persian and other Muslim itinerants who arrived in coastal Malabar must have utilised the existing system, as it was common across the Indian Ocean littoral. Early evidence comes from the mid-fourteenth century, when Moroccan traveller Ibn Batțūta $(1987,572-73)$ compares the succession customs in a Malabari port-town with the ones in bilād al-sawdān, broadly 'black Africa' but here referring to Western Africa, that is often identified as the matrilineal belt. ${ }^{9}$

In the sixteenth century, a local jurist-cum-historian, Zayn al-Dīn al-Malaybārī, wrote about the system in northern Malabar, although relating its origin with Hindus and despising Muslims for following such a custom. The passage quoted partially above is worth quoting again in full:

Inheritance right among the Nayar groups and those who are related to them is to their sisters from mothers, sisters' children, their aunts, and their children from the mother's side, not [to one's own] children, whether it is property or political power. This tradition of denying inheritance to one's own children has crept into the majority of Muslims in Kannur and the neighbouring areas, following them [the Nayars], despite the fact that they read the Quran, memorize and recite it beautifully, study religious knowledge, and occupy themselves with prayers. ${ }^{10}$

Zayn al-Dīn is not alone in distancing the custom from 'proper' Islam and its piety. Later

$9 \quad$ H.A.R. Gibb $(1929,810)$ translates the term "Sudān" as "negros" (from sawdān). The term "Bilād as-Sūdān" in premodern Arabic geographical literature stands for West Africa, what we identify today as the Sahel. Ibn Battūtata visited the region that visited between 1346 and 1349 after his travels in Asia, hence this comparison. For this important remark, I am grateful to Cliff Pereira. 
scholars wrote against it as much as many wrote in support of it. In the eighteenth and nineteenth centuries, the debates among supporters and opponents were intense and contributed to the advancement of the system with several changes (Kooria, forthcoming).

A better-known Muslim matrilineal group in Kerala is the royal household of Arakkal Ali Rajas of Kannur. Padmanabha Menon $(1924,539)$ gives two accounts on their origins. According to one, a Kolattiri princess had an alliance with a Muslim man, and the Kolattiri Raja allotted them a territory as a provision for the princess. The territory and the household were to conform to the matrilineal system of inheritance, "in spite of their religion." Another account, available in a version of Kêralolpatti, claims that Cheraman Perumal invited a Muslim man and his wife from their native land of Aryapuram and installed them at Cannanore. He was called Ali Raja. William Logan ([1887] 2010, 359) says that "tradition is tolerably unanimous that the first chieftain of the family was a Nayar," who was a minister of Kolattiri in the late eleventh or early twelfth century. He embraced Islam and adopted the name of Muhammad or Mammad Ali, yet the Kolattiri Raja retained him as his minister because of his skills. His successors were hereditary ministers of the Kolattiris, and they were admitted to all the important councils, and they stood on such occasions "with the sword's point resting on a box, implying by that, whatever decision was come to, they would find the money to carry it out" (Logan [1887] 2010, 360). The Arakkal has been at the vanguard of maintaining matrilineal tradition among Malabari Muslims with elaborate customs of women-centric lineage, inheritance of property and positions, celebration of female rites of passage, matrilocality, and they were at the forefront of several juridical and religious discourses on the substance of the system.

Among the Muslims of the Konkan coast, the existence of matriliny has long been attested among the Navayats in Kanara and Konkani Muslims in Ratnagiri (D'Souza 1953; Doddamane 2010). They were rarely taken into account in the context of heated legal debates around the aliya santāna law during the colonial period, but early traces of the praxis can be seen at the beginning of the second millennium CE itself. The Panaji Plates of Kadamba ruler Jayakesi I (r. 1050-1080) talk highly of one nauvittaka (ship-owner) Aliya, his son Madhumada and grandson Sadhan, who all belonged to "the line of the Tajiyas" (Moraes 1931, 399-400). He was a tajiya (from Ar. täjir), a merchant and nauvittaka (shipowner) of considerable wealth, and his son and grandson reigned in the vicinity of Goa. His name, Aliya, is often interpreted as Sankritization of the Arabic name Ali (Chakravarti 1999, 158; Doddamane 1993), but it could well be aliya itself, a term used in the region to indicate a brother-in-law (as in the name aliya santāna niyama for the system), and Madhumada and Sadhan must have been the aliya santānas or the children of the brother-in-law.

If the case of the Muslim community is comparatively well-known, other Abrahamic communities also used, contributed to and benefited from the system. They used matrilocality in order to gain access to the political, commercial and social networks, and used matrilineal succession in certain realms while they discarded it entirely in some others. Latest research by Ophira Gamliel (Forthcoming) sheds light on the Jewish practices of matriliny in the region. In the well-known Jewish Copperplate Inscription of a grant to the Jewish merchant-cumleader Joseph Rabban, the hereditary honour is prescribed for his nephews, together with his male and female issues. This prescription is revelatory on several grounds: first, it informs us that the royal house of the Cheras, the endower, gave importance to the matrilineal norms in its grants. Second, it also indicates that the Jewish leader was required to follow the matrilineal custom in case he was not already following it. It most likely that the grant was following 
what was already relevant for him, possibly he was already part of a matrilineal household through marriage or custom. Third, it might also reveal that the Jewish community at large was following the matrilineal tradition, even if a bit hesitatingly, as would become clear in a later instance.

In the twelfth century, a Jewish trader from Tunisia, Abraham ben Yijū, who "cohabitated with a Tulu Nair woman called Aśu, the sister of ben Yijü's business partner," who is named Nāyar (Gamliel 2018, 63), is advised to take his children from the region from being matronised (as in patronised) by the local norms. Abraham ben Yijū did manage to evade this network, but the advice shows the existence and prominence of the practice among the Jewish community and the way they intermarried with local matrilineal communities. Many Jewish fathers, along with Muslim and Christian Arabs, must have 'lost' their children to their mothers like this, generating knowledge and paranoia among their coreligionists in the Middle East. That is what motivated the Middle Eastern Jewish jurist to warn his colleague Ben Yijū against the social system. Furthermore, Gamliel $(2018,68)$ informs us that the Jewish Malayalam speakers used several terms that indicate their affinities with matrilineal household. Some examples are the terms onnāinkārnṇōru (communal elder) and taravātu (hereditary estate). She affiliates these terms mostly with Nāyar practice, but the terms must have been part of a larger pool of matrilineal lexicon prevalent not only among the Nayars but across the southwestern Indian matrilineal communes.

Similar to the Muslim and Jewish communities, the Arab, Nestorian and European Christians in the region also utilised the system at different levels. In the origin myths of Syriac Christians, recounted in the sixteenth century by the Portuguese sources as well as Syriac sources, St. Thomas (Thomas of Cana) is said to have maintained two families in Kannanur and Kodungallur, leading to a division among his followers and later Christians as the Southists (tekkumbhāgam) and Northists (vatakkumbhāgam). This division partly owes to the legendary belief that the Northists emanated from the union of Thomas with a Nayar woman (Swiderski 1988, 76). Needless to say that this myth is anachronistic, for the emergence of Nayar community happened long after the assumed life of Thomas in the region. Yet, it indicates the matrilineal staple ingrained in the myth of origins among some Syriac Christians. More solid historical reference comes in the ninth century when a land grant given to the community leader Mar Sapir Iso in $849 \mathrm{CE}$, the nephew appears as a legal heir to the grant (TAS, 2, no. 9 [I and II]). Similar to Jews and Muslims in the region, Christians were also referred to as mäppilas, as Nasrani (Nestorian) Mappilas, and maintained similar matrilineal usages, such as taravātu and muraccerrukkan/peṇnu.

Another evident form of matrilineal succession among Christians is priestly succession. The topmost positions of metrāns (similar to bishops) in the Syrian Christian church were nominated by the predecessors from a selected body of rambāns, whereas the ordinary positions of priests (kattanärs) were hereditary and passed through the matrilineal order, from uncle to nephew. Even so, all the nephews were required to pass "seven offices of ostiary, reader, exorcist, acolyte, sub-deacon and deacon before becoming priests" (Menon 1924, 490-91). ${ }^{11}$

Although the history of Christianity in southern India gives some insights into matrilineal influences in religious succession and hereditary titles, it should be noted that men in the community have been very hostile towards women's access to inheritance and property ownership, and maintained a very anti-matriliny sentiment. While all other communities in the region, even the patrilineal and patriarchal ones, allocated a share of inheritance to women, the Chris- 
tian tradition prevented women from equal access to property beyond the gift transmissions (Visvanathan 1993, 144-48). This situation continued well into the twentieth century despite constant attempts from within and outside the community. In the sixteenth and seventeenth centuries, different synods held in Goa pressed for granting women the right to inheritance. Some spokespersons endeavoured their best to convince their coreligionists how unjust and un-Christian this practice was.

In sum, it is clear that the matrilineal system is not a domain of a specific religion or its one group of followers, that is to say Hinduism and the Nayars. The foregoing discussion demonstrates that the Nayars in fact emerged in the region in the ninth and tenth centuries at the same time as the Islamic, Jewish and Christian communities were also increasing their presence significantly. The epigraphic and textual sources for the very presence of all these communities are almost contemporaneous, and the matrilineal customs in the region are marked by their simultaneous existence. The Brahmanical faith system spread along the southwest coast in the eighth century with a new life in the Tamilakam, when the Abrahamic religious traditions also spread in the region. The Brahmanical conjugal relations with the local population led to the emergence of the hybrid Nayars, just as Arab, Persian and African interactions would lead to the birth and rise of the Mappila communities with Islamic, Jewish and Christian affiliations. Therefore, it would not be accurate historically to say that one religion dominated the scenario and when people converted from that religion to other religions, the system also travelled along. The cases of Jews, Muslims and Christians demonstrate that each religion had its own contributions to different historical stages of the system.

\section{Question of Religious Conversion}

On the basis of the above discussion, how should one make sense of religious encounters and conversions with regard to matriliny? Should we separate religion(s) from the followers and claim that the religions did not recognise matriliny but the followers in these regions did? Indeed, this latter argument has been a major trend among scholars, not particularly in the case of matriliny but in the case of analysing the adherents of the religions in these areas as potential deviants from the religion vis-à-vis their counterparts in the regions where each religion originated.

Questioning the intersection of religion with matriliny in the subcontinent is therefore problematic and goes back to the origin of both institutions (matriliny and religion). The debate emerges from the discourses on the prehistoric period in South Asia, as the transition from matriliny and matriarchy to patriliny and patriarchy is understood in terms of a negotiation between Aryan and non-Aryan traditions, or, more specifically, between Brahmanism and non-Brahmanism, if not conversion from the latter to the former. In the early stages of this transition, Brahmanism arguably contained a composite lineage tradition, before it was 'taken over' by patriarchy. Kosambi $(1975,102-5)$ cites the Rigveda with indications of matrilineal descent for some Brahmans who were non-Aryans, too. While this serves his argument that not all Brahmans were necessarily Aryans, it also underlines that Aryanism was prominently patrilineal and patriarchal while the indigenous non-Aryan traditions were matrilineal and matriarchal. Similarly, he writes that Aryan sacralisation of certain objects was taken from non-Aryan traditions and incorporated into religious rituals. The mother-goddesses in triads and apsarasas are the best examples of this appropriation. The new priesthood encouraged the formation of a society out of Aryan and non-Aryan tribes, and it was "not [a] deliberate, 
conscious, planned action, but the result of hunger" and its "sole aim was to make a livelihood." The Brahmans penetrated non-Aryan tribes, took over new cults, and ultimately helped food-gatherers become food-producers (Kosambi 1975, 122, 134). In matriarchal communities, the priest was "a goddess-chief-priestess or member of a sisterhood," but the position in patriarchal groups was initially held by a tribal chief, clan head or a medicine man whose main duty was to petrify society, to discourage innovation, and to maintain the status quo and the class structure (Kosambi 1975, 24). In the transition from matrilineal/matriarchal to patrilineal/patriarchal systems, many clans endeavoured to accommodate both systems with double gōtra identifications, and they could utilize either gōtra as contexts required. "Some are Vasisthas by day, Kasyapas by night!": it was part of their self-adjustment mechanism by assimilating the existing maternal kinship line into the new patriarchal patterns (Kosambi 1975, 105).

Coming from such arguments in the broader context of the prehistoric subcontinent that are hard to substantiate with definite evidence, the southern Indian case is intriguing, for it is not a birthplace or heartland of any major Abrahamic or Indic religion. In spite of this, or because of this, all these religions have a strong historical presence in the region, especially in its coastal belts. The prominence of individual Indic religions changed from Jainism to Buddhism to Brahmanism over the course of the centuries, while Abrahamic religions found significant followership by the end of the first millennium CE. In this confluence of religions from outside, the region was not just a passive receiver. Rather, it contributed to these religions in its own ways, by incorporating local customs and traditions and catering to local necessities.

The matrilineal system provides an insightful framework to understand contributions of the people from the region to these major religions. Religious and regional boundaries become ambiguous and blurred here, as many communities criss-crossed in historical interactions, with mutual influences across matrilineal boards. For example, the Navayats in Karnataka emerged from Arab traders "settled amid the Jaina trading communities of the Konkan" (Thapar 2003, 332). The Navayats were matrilineal, but did they specifically receive the tradition from Jains? Possibly yes. Matrilineal Muslims in Kerala and Lakshadweep might have been influenced by Buddhism in general, in contrary to the wider narrative of the Hindu influence. In Lakshadweep, Sayyid Fathullah, a prominent $q \bar{a} d \bar{\imath}$ and religious teacher working in the Amini Island for more than half a century now, mentioned to me that the Muslims in the islands possibly converted from Buddhism to Islam, and the vestiges of matriliny are owed to Buddhist traditions. Similar matrilineal Buddhist-Islamic interconnections and conversion narratives can be found in southeastern Sri Lanka as well as in the Maldives and among the Minangkabau community of West Sumatra in Indonesia. These cultural criss-crosses and the Buddhist-Jain influences among matrilineal communities elsewhere, along with simultaneous community formations with Indic and Abrahamic inclinations, support the idea that matrilineal pedigrees in southern India had diverse contributors to its spread and survival. It is therefore injudicious to say that one community or religious group was the sole progenitor of the praxis and contributed to all other communities and groups in the region.

The normative orders adhered to by local religious communities should be understood as part of the religion. Matriliny is such a case that the historical writings on these religions should take into account to see how followers brought together local traditions along with religious prescriptions and proscriptions and what the continuities and ruptures in this regard were. Instead of understanding them as only local expressions, syncretic traditions or even deviations, they should be understood as the creative ways in which the adherents of these 
religions contributed to their historical making. As in the case of Islam, matrilineal Muslims are very much part of Islam's history, and they should not be marginalised in the narratives on the doctrines, laws and histories of this religion. The same goes for other Abrahamic and Indic religions. Notions of religious-regional specificities in southern India thus should be explored further against the background of social institutions such as marriage, family, habitation, inheritance and property regimes.

\section{Conclusion}

During their months- or year-long stay in the coastal areas and port towns of the Indian Ocean littoral, waiting for favourable winds and monsoon for the next leg of their journey, the itinerant travellers married into the local population and established family ties. Such marriages often necessitated compromises and compliments from both sides, financially and socioculturally. The overall framework of the matrilineal system made such exchanges smooth, and it thus became entangled with oceanic cultures. For the mobile traders and itinerants, whether Abrahamic or Indic, the marriage into local communities was a significant stepping stone in the making of social, commercial and political alliances. From the perspective of local communities, these husbands brought not only financial stability but also a network of larger oceanic, mercantile and religious prospects. The matrilineal and maritime framework thus facilitated transregional and regional exchanges.

This dimension also helps us question the existing popular and academic narratives on the system's prevalence among the Hindu Nayars. Such a claim of an exclusive origin of the system from a single source and its impact on other religious and caste groups is problematic on various grounds. This essay has demonstrated that the system did not emerge from among the Nayars to motivate other groups to follow it, and they were not its breeding grounds vis-à-vis other contemporary communities. The Nayars developed as a caste group in the ninth and tenth centuries, at the same time as Abrahamic communities such as Muslims, Jews and Christians also formed their presence in the region and underwent similar social and historical processes following the Buddhist and Jain prominence in the region. Therefore, some practices of the Kerala matrilineal Muslims have more in common with the (Jain) Bunt matrilineal groups of Tulunatu than with the neighbouring matrilineal Hindu Nayars.

The matrilineal praxis among different religious communities has often been identified as syncretic and hybrid vis-à-vis the histories of religions. Against this trend, this article suggests that the followers of Indic and Abrahamic religions contributed to the various expressions of their religions through an amalgamation of regional traditions, and that these dimensions should be taken into account as important doctrinal elements and historical makings of the religions as such. The absence or unavailability of a written corpus often stood as excuse in the course of such explorations for earlier scholarship, but that is no longer tenable in this world of increasing interdisciplinary promises of historical anthropology and ethno-history, along with the availability of multi-lingual archives across religious and regional borders. Various fragmentary yet significant sources discussed in this study demonstrate the potential ways in which the adherents of different religions incorporated the matrilineal system in their socio-cultural lives while simultaneously being fully dedicated adhesive to the respective faith system. Their amalgamation of such regional elements with the universal aspirations of the religions should be taken into account as part of the religions' doctrinal mould itself. Along these lines of matriliny we can also observe several other shared traditions and histories 
among the Indic and Abrahamic communities in southern India. This communality is explicit in such Buddhist-Jain and Abrahamic institutions as palli (the worship place, in contrast to the Hindu temple), communities (such as mappilas), rituals (such as nerccas and perunnals) and practices, and they require further in-depth explorations in order to get a comprehensive picture of premodern social formations in the region. This would help us analyse their traditions as part of the broader historical and human experiences of the concerned religions, instead of perceiving them as deviations from and contradictions to normative orders.

\section{Acknowledgment}

For their various comments and inputs, I am extremely grateful to Ophira Gamliel, Alexandra Cuffel, Lekshmi Chandran, István Perczel, Michael Tharakan, Susan Visvanathan, Rachel Varghese, Ines Zupanov, and two anonymous reviewers of Entangled Religions. Earlier versions of this essay were presented at a workshop at the Centre d'Études de l'Inde et de l'Asie du Sud in Paris on 29 April 2019 and in a webinar series of the Kerala Council for Historical Research on 10 December 2020. I am also thankful to the organizers and audience of both the events for their constructive feedback. Any inadvertent errors are my sole responsibility.

\section{References}

Abraham, Janaki. 2017. "Setting Sail for Lakshadweep: Leela Dube and the Study of Matrilineal Kinship." Indian Journal of Gender Studies 24 (3): 438-54.

Arunima, G. 2003. There Comes Papa: Colonialism and the Transformation of Matriliny in Kerala, Malabar, C. 1850-1940. New Delhi: Orient Longman.

Ayyangar, M. S. Ramaswami. 1922. Studies in South Indian Jainism. Madras: Hoe \& Co.

Bharathi, S. B. 2004. "Matriliny in South India with Special Reference to Tamil Nadu." International Journal of Dravidian Linguistics 33 (2): 195-202.

Burnell, A. C. 1894. "The Devil Worship of the Tuluvas." The Indian Antiquary 23: 1-99.

Chakravarti, Ranabir. 1999. "Candrapura/Sindabur and Gopakapattana: Two Ports on the West Coast of India (AD 1000-1300)." Proceedings of the Indian History Congress 60: 15361.

Davis Jr., Donald R. 2013. "Matrilineal Adoption, Inheritance Law, and Rites for the Dead Among Hindus in Medieval Kerala." In Religion and Identity in South Asia and Beyond: Essays in Honor of Patrick Olivelle, edited by Steven Lindquist, 147-64. London: Anthem Press.

Dikshitar, V. R. Ramachandra. 1939. The Śilappadikāram. Madras / Oxford University Press.

—_. (1933-1934) 1966. "The Marumakkattāyam and the Sangam Literature." Zeitschrift für Indologie und Iranistik: Herausgegeben im Auftrage der Deutschen Morgenländischen Gesellschaft 9: 255-67.

Doddamane, A. Wahab. 1993. Muslims in Dakshina Kannada: A Historical Study Upto 1947 and Survey of Recent Developments. Mangalore: Green Words Publication.

- 2010. "Matriliny Among the Nawayaths of Bhatkal." In CIESCO Golden Jubilee Souvenir, 219-21. Calicut: Prameela Press.

D’Souza, Victor S. 1953. "Mother-Right in Transition." Sociological Bulletin 2 (2): 135-42.

Dube, Leela. 1969. Matriliny and Islam: Religion and Society in the Laccadives. Delhi: National Publishing House. 
Ehrenfels, Umar Rolf. 1941. Mother-Right in India. Hyderabad: Oxford University Press in the Government Central Press.

Ehrenfels, U. R. 1953. "Matrilineal Family Background in South India." The Journal of Educational Sociology 26 (8): 356-61.

Eller, Cynthia. 2011. Gentlemen and Amazons: The Myth of Matriarchal Prehistory, 1861-1900. Berkeley: University of California Press.

Fawcett, F. 1903. "The Kondaiyamkottai Maravars: A Dravidian Tribe of Tinnevelly, South India." Journal of the Royal Anthropological Institute 33: 57-65.

Forbes, Andrew. 1978. Studies in Indian Ocean Islam: Caste and Matriliny in the Laccadive Islands. London: Routledge.

Gamliel, Ophira. 2018. "Back from Shingly: Revisiting the Premodern History of Jews in Kerala." Indian Economic and Social History Review 55 (1): 53-76.

—. Forthcoming. "Matrilineal Jews or Slave Descendants? Halakhic Laws and Trade Alliances in Medieval Malabar." In Customizing Sharia: Matrilineal Muslims in the Indian Ocean, edited by Mahmood Kooria.

Gaur, R. C. 1974. "The Legend of Purūravas and Urvaśĩ: An Interpretation." Journal of Royal Asiatic Soceity 106 (2): 142-52.

Ghosh, Amitav. 1992. In an Antique Land. New York: A. A. Knopf.

Gibb, H. A. R. 1929. Travels in Asia and Africa, 1325-1354. Translated by H. A. R. Gibb. 4 vols. London: George Routledge \& Sons.

Goitein, Shelomo Dov, and Mordechai A. Friedman. 2008. India Traders of the Middle Ages, Documents from the Cairo Geniza ("India Book"). Leiden: Brill.

Goody, Jack, and S. J. Tambiah. 1973. Bridewealth and Dowry. Cambridge: Cambridge University Press.

Gough, Kathleen. 1954. The Traditional Kinship System of the Nayars of Malabar. Cambridge, MA: Harvard University Press.

Gundert, Hermann. 1872. Malayalam-English Dictionary. Mangalore: C. Stolz / Basel Mission Book and Tract Depository.

Honko, Lauri. 1998. The Siri Epic as Performed by Gopala Naika. Helsinki: Suomalainen Tiedeakatemia, Academia Scientiarum Fennica.

Ibn Bațūṭa, Abu 'Abd Allāh Muḥammad. 1987. Rihlat Ibn Bațūṭa: Tuhfat al-nuzzar fi ghara'ỉb al-amsar wa-'aja'ib al-asfar. Edited by Muhammad 'Abd al-Mun'im al-'Uryān and Musțafā al-Qașșāṣ. Beirut: Dār Ihyā' al-'Ulūm.

Jordanus, Friar. 1863. Mirabilia Descripta: The Wonders of the East. Translated by Henry Yule. London: Hakuyt Society.

Kapadia, Karin. 1994. "Bonded by Blood: Matrilateral Kin in Tamil Kinship." Economic and Political Weekly 29 (15): 855-61.

Karve, Irawati. (1953) 1965. Kinship Organization in India. Bombay: Asia Publishing House.

Kieniewicz, J. 1986. "Pepper Gardens and Markets in Precolonial Malabar." Moyen Orient et Océan Indien 3: 1-36.

Kodoth, Praveena. 2002. Framing Custom, Directing Practices: Authority, Property and Matriliny Under Colonial Law in Nineteenth Century Malabar. Trivandrum: Centre for Development Studies.

. 2004. Shifting the Ground of Fatherhood: Matriliny, Men, and Marriage in Early Twentieth Century Malabar. Trivandrum: Centre for Development Studies. 
Kosambi, D. D. 1962. Myth and Reality: Studies in the Formation of Indian Culture. Bombay: Popular Prakashan.

- 1975. An Introduction to the Study of Indian History. Bombay: Popular Prakashan.

Kumar, V. Vijaya. 2006. Traditional Futures: Law and Custom in India's Lakshadweep Islands. New Delhi: Oxford University Press.

Kunjan Pillai, Elamkulam P. N. 1970. Studies in Kerala History. Kottayam: National Book Stall. Kutty, Abdul Rahman. 1972. Marriage and Kinship in an Island Society. Delhi: National Publishing House.

Lambourn, Elizabeth. 2018. Abraham's Luggage: A Social Life of Things in the Medieval Indian Ocean World. Cambridge: Cambridge University Press.

Logan, William. (1887) 2010. Malabar Manual. 2 vols. New Delhi: Asian Educational Services. McGilvray, Dennis. 2008. Crucible of Conflict: Tamil and Muslim Society on the East Coast of Sri Lanka. Durham: Duke University Press.

Menon, K. P. Padmanabha. 1924. History of Kerala Written in the Form of Notes on Visscher's Letters from Malabar. Ernakulam: Cochin Government Press.

Minakshi, C. 1938. Administration and Social Life Under the Pallavas. Madras: University of Madras.

Monius, Anne E. 2001. Imagining a Place for Buddhism: Literary Culture and Religious Community in Tamil-Speaking South India. New York: Oxford University Press.

Moraes, George M. 1931. The Kadamba Kula: A History of Ancient and Medieval Karnataka. Bombay: B. X. Furtado \& Sons.

Narayanan, M. G. S. 2013. Perumāls of Kerala: Brahmin Oligarchy and Ritual Monarchy. Thrissur: Cosmo Books.

Nilakanta Sastri, K. A. (1935) 1955. The Cōlas. Madras: University of Madras.

- (1955) 1958. A History of South India from Prehistoric Times to the Fall of Vijayanagar. Madras: Oxford University Press.

Orr, Leslie. 2000. "Women's Wealth and Worship: Female Patronage of Hinduism, Jainism, and Buddhism in Medieval Tamilnadu." In Faces of the Feminine in Ancient, Medieval and Modern India, edited by Mandakranta Bose. New York: Oxford University Press.

—. 2015. "Non-Wives and Their Networks in Medieval Tamilnadu." In Looking Within/ Looking Without: Exploring Households in the Subcontinent Through Time, edited by Kumkum Roy. New Delhi: Primus Books.

Perry, Craig. 2014. "The Daily Life of Slavery and the Global Reach of Slavery in Medieval Egypt, 969-1250 CE." PhD diss., Emory University.

Raghavan, M. D. 1971. Tamil Culture in Ceylon: A General Introduction. Colombo: Kalai Nilayam.

Ramesh, K. V. 1970. A History of South Kanara: From the Earliest Times to the Fall of Vijayanagara. Dharwar: Karnatak University.

Shukkur, Sheena. 2007. "Scope and Application of Muslim Family Law in Kerala and Lakshadweep: A Study of Legislative Provisions and Distinct Local Laws." PhD diss., Tamilnadu Dr Ambedkar Law University.

Sirisai, Solot, Sinee Chotiboriboon, and Charana Sapsuwan. 2017. "Matriarchy, Buddhism, and Food Security in Sanephong, Thailand." Maternal \& Child Nutrition 13 (suppl. 3): $1-10$.

Swiderski, Richard Michael. 1988. "Northists and Southists: A Folklore of Kerala Christians." Asian Folklore Studies 47 (1): 73-92. 
Tambiah, H. W. 1954. The Laws and Customs of the Tamils of Ceylon. Colombo: Tamil Cultural Society of Ceylon.

Tambs-Lyche, Harald. 2018. Transaction and Hierarchy: Elements for a Theory of Caste. Oxon: Routledge.

Thapar, Romila. 1966. A History of India. Vol. 2. Harmondsworth: Penguin Books.

- 2003. The Penguin History of Early India: From the Origins to AD 1300. London: Penguin Books.

—. 2013. The Past Before Us: Historical Traditions of Early North India. Cambridge: Harvard University Press.

Veluthat, Kesavan. 1978. Brahman Settlements in Kerala: Historical Studies. Calicut University: Sandhya Publications.

Visvanathan, Susan. 1993. Christians of Kerala: History, Belief and Ritual Among the Yakoba. New Delhi: Oxford University Press.

Waihong, Choo. 2017. The Kingdom of Women. London: IB Tauris.

Zvelebil, Kamil. 1973. The Smile of Murugan: On Tamil Literature of South India. Leiden: E. J. Brill. 